\title{
Which theory of Democracy?
}

\author{
Tommaso Visone \\ Università degli Studi Roma Tre \\ tommaso.visone@gmail.com
}

Democracy. Nowadays, this term is used quite freely but by going beyond its literal meaning (demos = power) we can find a lot of other possible interpretations that generate the political need to ponder over the historical meaning of the word. In the article the two main and different theories of Democracy, contemporary and ancient shall be explained and confronted in order to fully understand what can be intended as current Democracy. The objective is also, as indicated in the title, to answer the question that set up a contrast between the two main theories (which theory of Democracy? The Ancient or the contemporary one?) showing that contemporary Democracy was influenced by the Ancient theory proving that the answer is to be found in the ever different relationship existing due to the specific historical moment in which such confrontation was made and not between to opposing and contrasting worlds.

This short essay will try to explore the universe of Democracy's theory via a critical approach and an historical feeling to the praxis and values related to the problem of democracy with the hope to better define the current meaning of the word. This essay is divided into five parts:

- In the first part, the meaning of the political theory and the methodological choice adopted into the work is analysed.

- In the second part, the problems linked to the theory of classic democracy are dealt with.

- In the third, the contemporary theory on Democracy is explained.

- In the fourth part, some criticism on the current mainstream interpretations of the theory of Democracy is argued.

- In the fifth part conclusions and hypothesis are formulated

Because of the short length of the paper and of the complexity of the issue, all the possible interpretations and problems linked to it cannot be fully addressed in the way that a longer work would. However, the issues and interpretations that are deemed essential in order to better understand and clarify the theory of democracy have been selected. 
Theory is a word that can be used with a lot of meanings. According to A.Marradi "theory" has plenty of possible definitions, that can be included in a vast typology (Marradi 1984: 157-171). In this essay, the definitions of theory specifically needed is the one that can later define the meaning of Democracy. The problem of political theory stems from a debate on the roles and the relationship existing between political science and political philosophy that has been an important issue of study of the methodological and "geographical" redefinition (Sartori1979; Zolo 1985; Bobbio 1986; Bobbio 1990) since the early ' $80 \mathrm{~s}$. Beyond the differences among the personal views, the many different possible solutions that came up from the debate, a common opinion was that political studies need a common "theory", that analyses the "fundamental political concepts"(Bovero 1999: XX), constituting a platform to increase political knowledge. Sartori gives a plausible and effective approach to define this common "new" tool: "I understand it (the theory) as a third kind, a level of intermediate subject of discussions between philosophy on the one hand, and science on the other. Philosophy can be all ideas and no facts, science (empirical) all facts and no ideas. The theory here shown lies in the middle: ideas hold on to facts and vice versa, facts incorporate into ideas" (Sartori 1995: 8). The same statement is found among the observations by Bobbio that address a second standpoint on political philosophy concerning the "facts" specifically when political philosophy is involved in the conceptual analysis "continuously interlaced with factual analysis...to be performed with the consolidated methodology of empirical science."(Bobbio 1990:39). These considerations by Bobbio are close to Sartori's ideas; the difference lies in the name because Bobbio calls this second standpoint on political philosophy corresponding to Sartori's political theory "general theory of politics".

Even though the short definition for "Political Theory" is a consideration about the meanings of political language that initially keeps the two different points of view on research (on to be meaning and on the should be meaning) separated, it actually tries to find a link between the descriptive and prescriptive meanings of the analysed word.

\section{Theory of classic Democracy}

Democracy is known to be born in ancient Greece around the VI century B.C. This notion may be criticized (Sen 2004; Erodoto 1990: 297) or not (Sartori 2006: 54) but, for the purpose of this article, ancient Greek Democracy must be mentioned to spot the possible links to "contemporary" Democracy that was surely born in Western countries, culturally inspired by the Greek model (Canfora 2004: 52-79). The term Demokratia was found for the first time (Canfora 2004: 31; Musti 1997: 3) in Erodoto's Istoriai (V century B.C.) when he spoke about the debate that took place in 522/521 B.C among Persian notables on the best possible form of government. Most likely, the first empirical case of Democracy came out in Chio around the middle of the VI century B.C. (Held 1997: 29) and the apex of this experience was reached in Athens around the $V$ century B.C. The Athenian system was marked by three important reforms: Solon's reforms (594/593 B.C.) that prohibited slavery as punishment for debt introduced a monetary reform and created a first form of isonomia (D'Addio 
1984: 14); Clistene's reforms (508/507 B.C) that created the Athenian Democracy through the institution of ten new tribes based on residence, the transformation of the political role of the demi, the creation of bule and prytaneía (Musti 2003: 91-92); Efialte's reform (461 B.C) that concentrated all the democratic powers into the ecclesia through the abolishment of Aereopago's powers (Musti 2003: 113). This type of Democracy was characterized by: direct participation of citizens to legislative and judicial functions; sovereign power of the assembly of citizens; sovereignty of the assembly on all public affairs; several methods of selection of public candidates (election, rotation, draw); short duration of the offices; economical compensation for the public office officials (Held 1997: 56; Bobbio 1987: 3-17; Finley 1973: 19).

Furthermore, this type of Democracy relied on a limited citizenship and on strong slavery (Canfora 2004: 52-79). The above mentioned characteristics are the descriptive ones.

Issues on the prescriptive meaning of the classic Democracy controversial interpretations can be found in authors, as Musti (Musti 1997) and Canfora (Canfora 2004). The debate is focused on the possible links between Democracy and freedom in the famous Pericle's speech contained into the Tucidide's Istorie. Canfora asserts that, to Tucidide's Pericle, Democracy was in contrast with freedom and Musti asserts the opposite of Canfora. This debate is important because Pericle's speech is considered an exposition of the classic Democracy's model and at the same time it is hard to find an important Greek democratic theorist who helps research on this subject (Held 1997: 33). Consequently, the prescriptive meaning of classic Democracy has to be found through a different point of view, based on the principles that most experts believe to be fundamental in classic Democracy context. These values are isegoria and isonomia among citizens and the "civic virtue" among the same citizens (Held 1997: 32-35; Finley 1973: 16-19; Sartori 2000: 154-155; Canfora 2004: 31-51; Musti 1997: 3-62; Bobbio 1987: 3-16). In the end, it is possible to say on the classic democracy's prescriptive meaning that it is linked to the above mentioned values, and that a possible definition of ancient Democracy, in the complex relationship between descriptive and prescriptive meanings, is delineable as the direct government of the polites on the polis that is inspired by the political and juridical equality of the citizens and by the belief that the "civic virtue" of the same citizens is the only possible way to eunomia (on this point look Zeus' answer into Protagora by Platone). The classic theory was described in such view by Enlightenment thinkers who newly proposed the word "Democracy" into their papers, after a long silence over this old concept and their ponderings would have a strong political impact (Cofrancesco 2003: XVIIXIX). Montesquieu, according to Polibio's typology and inspired to classic Democracy, (Musti 1997: 314), said that the principle of Democracy is "virtue" of the people (Montesquieu 2005: 84) and its nature is to be a Repubblic where all the people detain the supreme power (Montesquieu 2005: 66); Rousseau's work, characterized by a deep knowledge of classical political experiences (Carnevali 2002: 259-260) was interpreted by French revolutionaries who, 
sometimes by changing this original thought (like Saint-Just in Sur la costitution de la France, Musti 1997: 323) linked Rousseau's ideas on Democracy to the French Revolution. At the same time, American constituents called "Republic" the new American State having likely been influenced by Montesquieu's thoughts (Dalh 2003: 114-115). In the whole, the XVIII century saw the rebirth of study on classic politics and Democracy that marked the political future of the world creating the concept that is currently attributed to classic Democracy.

\section{Theory of contemporary Democracy}

Nowadays, the world of political systems is dominated by concepts of Democracy. According to Bobbio it is possible to say that this is L'ére des démocraties (Bobbio 1995a: XIII). In fact, since the end of XX century, Democracy can claim victory over other political systems based on legitimacy due to the widespread belief that the only power to which free obedience is due, is power obtained through people's choice, that is elected following a system that recognizes the choices of a wide base of electors who determine their own representatives (Sartori 2000: 268-269). Such victory doesn't mean that Democracy has won into a global geographic area; (nowadays, the number of the independent states is about two hundred and the number of democracies is eighty six), even though in the last twelve years of the XX century the number of democracies doubled from forty (1960-1970) to eighty or so (Morlino 2003: 12 and specifically for period 1981-1985 Dalh 1989: 241).Consequently, it becomes important to fully understand the new meaning of the word Democracy, and how it has become so.

To answer this question, it is better to quickly delineate the historical contest and the historical reasons that lead in approximately two centuries (1789-1989) to the triumph of such concept and to the development of the contemporary empirical Democracy. Leaving out the Medieval experience such as the Viking Ting (Dahl 2002: 20) and Medieval ponderings on the theoretical sovereignty of the people (Bobbio, Pasquino \& Matteucci 2004: 236-237) it possible to say that before the XVIII century, as stated above, the Democratic (by" Democratic" it is intended the ideas that at that time would be known through the study of Classic Democracy) ideas were marginal into the political thought and marginalized into the political praxis of the time.

In this instance, it is best to delineate the specific context of the XVIII century where it is possible to delineate a new feeling about Democracy and with its political praxis and values. Such context was the French Revolution. Differently from the American war of Independence, it meant a radical rupture with its cultural and social roots (Sartori 2000: 39) and in this sense it is possible to speak about "Revolution" (Sobul 1997: 45-49). The Revolution lead to the moral and political need of universal values and normative models to use to substitute old and stratified social models that were destroyed the Revolution itself. These models were found into the ideological interpretation of the experience lived by Greek and Roman history in the classic city that, as ancient republics, 
gave to revolutionaries a model of virtue which convinced them that equality and freedom could coexist (Canfora 2004: 71-73). Between 1792 and 1793 Sansculottes went towards the praxis of direct government and towards the establishment of a People's Democracy (Soboul 1997: 240). the political activities of the Sans-Culottes "sections" were reformed by the same Jacobins (9 September of 1793) but their experience, united with the Constitution of 1793 that gave social equality a strong position in the revolutionary values, marking the strong attempt (as Marx understood in Holy Family when he spokes about the contradiction of Jacobins; Marx \& Engels 1972: 159) to propose (in an ideological and distorted way) classic Democracy mixed with the universal new values of the French Revolution.

The American approach to Democracy was different and came shortly after. Its birth came from the debate and the development of Christian values after the War of Independence. It was successful first as a praxis and then after as a theory (Urbinati 1997: 6-77). The American constituents were in favour of the Republican system but they were against Democracy because, differently from the French Montagnards politicians, they were afraid of direct (so Classic) Democracy (Bobbio 1995b: 141). James Madison wrote that democracies have always been violent and in contrast with all possible forms of guarantee for people or things (Hamilton, Jay \& Madison 1788: 61). So, in spite of work of intellectuals as T. Paine who spoke about Athens like an America in miniature (Paine 1995: 233), the concept of Democracy had to wait to become popular. But in the same period, the fusion of the new egalitarian Christian thoughts and values sprung from the war against the Brits (the same war springs from a reinterpretation of English values; Urbinati 1997: 79), paved the way to that "democratic individualism" that created the social Democracy, marked by equality, that Tocqueville saw in 1831 (Sartori 2000: 13). In fact, Tocqueville wrote as a central point to all his observation in its famous introduction at Démocratie en Amérique that the thing that had upset him the most was the equality of conditions because it was the generative force from which everything he had experienced during his journey in the States seemed to derive (Tocqueville 1968: 15). Tocqueville's observations would have likely been different if a whole lot of economical and political changes hadn't taken place between the end of the 20s and the early 30s of the IXX century (Testi 2003:145). In these years the premiership of A. Jackson and the economic situation lead to big social mobility and to the success of the self-made man that united with the new Christian thought (Unitarian church, etc.) founded a new "Democratic" society (this is the reason why it is possible to claim a slightly later success of Democracy in the US., because the 20s and 30s marked the end of a cultural process, after the different but also democratic French experience), that reflected a different society compared to the one of Washington and Jefferson. It was intelligently described by Tocqueville who, starting from Plato's typology, understands the new "democratic" contents of this particular society.

Summarizing of the relationship with Democracy, it is possible to say that the French way was different from the American one. In France it was the result of 
a great social, political and cultural rupture; whereas in America it was the result of a social and cultural evolution. On these different approaches it is possible to say again that French historical typology of democracy was basically rationalist and American historical typology was basically empiricist (Sartori 2000: 39). Clarifying this two different historical products that strongly marked the evolutions of contemporary Democracy, it is possible to assert that after the birth of these two prototypes the majority of European representative states (the way of birth of European representative states would need an other separate paper) experienced a process of democratization along two different lines: from widening the right to vote to universal suffrage and from political associations to mass parties (Bobbio 1995b: 144). These two lines are linked with the fights of national independence that characterize all the contemporary age and with the success of the national state. In fact, between the eighteenth and the nineteenth century, the new idea of national identity became current and strong, deep-rooted in the romantic experience (Chabod 1974: 23). This idea, connected with the universal values of equality and freedom (a typical example is Mazzini and his connected ideas of nation and humanity, Chabod 1974: 80), created big excitement to reform and revolt against the coincident pre-democratic and pre-national political system (the best example is the Asburgic Empire after Wien's Congress). In general after the end of Wien's congress (1814-1815) there was an increase in political and social unrest, where the request could be National, Liberal, Socialist or Democratic or a mix of the three. This fact, in the history of political thought, can create some problem, and it can create some problems also to who wants to rebuild the Democratic experience. In fact in Europe, from the French Revolution of 1789 to European risings of 1848, the term "Democratic" marked a crowd of different political positions that were united by the hate towards the census suffrage (Canfora 2004: 102). The same Communist Manifesto wrote by Marx in 1847 contained the claim that the first step for the Communist to take would be the conquest of Democracy (Marx \& Engels 1999: 35), evidently through the conquest of universal suffrage. After 1848 the different ways of progressive liberals, democratic and socialist became more delineable. Leaving out the socialist ideas - to better understand after the specific relationship between liberalism and Democracy- that here need to be reduced (but they were more complex and rich) to the Marxist point of view on instrumental Democracy directed to the conquest of the power by proletariat, it is possible to try to build a differentiation, according to Cofrancesco, between liberalism and Democracy. To simplify, Cofrancesco uses three containers: the first one is Anthropology and History; the second one is civil society, the third one is State and Politics.

In the first one, for liberalism the subject's dignity is linked with being in the world, with his human nature, and according to this point of view, political rights for all people aren't so important to obtain happiness and liberty, because the vote is considered as a function entrusted with the capability to do it well and not as a right. Moral universalism exists to Democracy as well but dignity isn't linked with his being in the world because it is linked with the capability to become worthy of citizenship doing something for the homeland. 
These distinctions lead to two different ideas of freedom, the liberal idea where freedom stays for "freedom from" whereas freedom in democratic idea stays for "freedom to". At the same time, the difference on History lied on a particular form of Historicism (that isn't the Popper's historicism) who stays for awareness of complexity of human vicissitudes for liberal thought whereas the democratic point of view on History is a type of secularized providence that is similar to a strong historical philosophy. In the second container liberalism see society as a society where the social relationship is a "limited performance", where the individual isn't linked strongly with society and live in a regulate conflict that allows to the bests to emerge whereas to democratic society is an organic union of partners where exist the value "one to everybody and everybody to one" and the aspiration is towards harmony with the tendency to limit conflict. Consequently there is a different conception of people: to liberalism it has value only as public opinion wise and competent that is composed by some whereas to Democratic the people is composed by the entire citizen, everybody is equal in the same country. In the third container liberalism has fear of sovereignty because it think that the individual right comes before the political union whereas to democratic thought the people has right to detain and use to itself the sovereignty that, consequently is seen as a good thing. Such points of view on sovereignty are due to a different vision of legitimacy. This one isn't so important for liberalism because it is interested in how the government governs and not, as the Democracy, in who governs. To Democracy there isn't legitimacy if the people isn't sovereign (Cofrancesco 2003: 57-64). At the end of this model is useful to observe that the epistemology linked with these two thoughts shows the same difference who presents the revolutionary French and American types of New Democracy. In fact, democratic thought is, epistemologically, rationalist as the French type and the liberalism is, epistemologically, empirical, as the American type. It is, told this, strange to see that this two different thoughts (and linked political praxis), often so distant, combined together have created our idea and experience of Democracy. But it is so.

And the reasons of this strange marriage are to find into two specific experiences, the French of third republic and the England of universal suffrage that united to the particular American system (that remains the same, or so, of the type described above) after the two word wars resulted, with different events, winners with the communist system. The alliance between liberalism and Democracy gushed out in these two countries as an outcome of the rupture of the dualism between political revolution and industrial revolution (1789-1848). After 1848 the industrial revolution became the first. The unexpected expansion, vast and boundless, of the capitalistic world economy opened into the advanced country political alternatives. The rulers of the more advanced European country started to admit, with reluctance, that a parliamentary constitution with wide suffrage was inevitable and, at the same time, it was likely politically innocuous (Hobsbawm 1979: 4-5). They begin to extend the suffrage towards a democratic point of view.

But at the same time liberalism was, and remained, in power (in England) and took the power (in France) because it represented the only possible economical 
policy that was considered reasonable for development. So, progressively the political mix between universal suffrage and liberal system came into being with the name of "liberal Democracy" where because of the insertion of people's vote into a bureaucratic vertical system (in other words, the modern State, Sartori 2000: 141) and because of the mix with liberal representative institutions there was the creation of representative Democracy that, differently to Classic Democracy, gives the people only the power to elect its representatives. It is also possible to say that the mix between Democracy and liberalism was based on a common rejection of socialism and communism due to the fact that the democratic thought was always (Robespierre included) in favour of private property, even if its aim was its distribution to all citizen, (Cofrancesco 2003: 62) whereas the central aim of communist and socialist ideas had always been the end of private property (Fenske 2004: 67-82). In the French case, there was a break in 1871 when, after the defeat against the Germans, there was a Civil war (according to Marx 1948) between the socialist Commune of Paris and the provisional government of A. Thiers. Communards had begun a socialist revolt (they also repurposed a form of direct democracy) and the central government, expression of a capitalist bourgeois force, isolated them, with the indifference of the other nations, and killed them all with the assent of the German occupants. This was the act of birth of the third republic in France (Canfora 2004: 176), that marked the momentary defeat of communist and socialist forces and also the substantial elimination of direct Democracy from Europe. The third republic represents, initially, (since the constitution of 1875) the classic example of a mix between democratic universal suffrage (only male in the nineteenth century) and a liberal balance of power, creating a republican model of parliamentarism that would influence the future empirical model of Democracy. The other model that can be useful to delineate a map of the mix between liberalism and Democracy is the English model of continuous evolution.

In fact, differently from France, the English model to arrive at liberal democracy was characterized by progressive reform and social stability. The Liberals and the Conservatives (lead by Gladstone and Disraeli) in the course of time gradually extended the suffrage (e.g.1867, 1884) creating a political praxis of useful reformism, even though there was a strong Trade Unions movement (Matthew 2002: 395-444). The arrival to the definitive model of liberal democracy was, for this graded reformism, slower than other countries (in England the universal suffrage was adopted in 1928) but the type of liberal Democracy that was created in the U.K was to be adopted by a lot of future democracies, in fact A.Lijphard calls it, in a famous study on contemporary Democracies, "Westminster" model (Lijphard 2001: 27).

Once we have individuated the prototype of the mix between liberalism and democracy, it is important to say that during the XX century, this model suffered a strong crisis in the period between the two Word Wars when due to a severe economical crisis it nearly disappeared, defeated by the Fascist governments that between 1921 and 1939 replaced it in almost every country of Europe. Only the ambiguous alliance with Communism (that since 1917 
governed Russia) and the consequent victory during the World War II saved and re-proposed a liberal Democracy that came into its "golden age" (Hobsbawm 2004: 18) by extending itself to women voters, containing social rights and elements of welfare state. Its subsequent confrontation with the Communist system ended on 9 November 1989 when, with the fall of the Berlin wall, real socialism came down as well. So it is possible to say that liberal Democracy remained alone among the great political systems (Fukuyama speaks even about "the end of history", Fukuyama 1992) and is, in terms of legitimacy, today the strongest political system of the world.

After having shortly clarified the historical evolutions of Democracy in the last two hundred years, it is necessary to adjust the descriptive and the prescriptive definitions of the term according to the current meaning of the term.

It is possible to have three types of empirical definitions: procedural, minimal and "condensed". The Procedural one looks at the procedural rules that characterize contemporary Democracies as a whole, or rather it looks at the method of the democratic praxis. Schumpeter wrote about the above in 1942, stating that the democratic method is the institutional shrewdness needed to arrive at political decisions, in which somebody acquires the power to decide through a competitive struggle for votes (Schumpeter 1942: 269). Kelsen wrote about the same issue that Democracy is a form as method and procedure, because a social system that transforms itself is to be considered formal in order to be distinguished from the contents of the system itself. (Kelsen 1981: 191). It is possible to say that the forms allow and guarantee the possibility that some substantial decisions are made following the ways that the same forms provide for it (Morlino 2003: 23).

The Minimal definition concerns the essential aspects (empirically checkable) that allow to decide a threshold beyond which a regime isn't considered as democratic. Bobbio wrote that in order for Democracy to be such, three characteristics need to be present: the right of a high number of citizens to participate directly or indirectly to public decisions; the existence of procedural rules like the majoritarian rule; the possibility for the voters and the governing authorities to choose amongst real alternatives (Bobbio 1995a: 6). It is important to stress (and here there is the usefulness of the Minimal definition) that if these characteristics aren't part of the system, it will be impossible to have any sort of Democracy.

The "Condensed" definition concerns the general empirical traits that are observable in all the contemporary democracies and it constitute an attempt to summarize the ideas included in the other two definitions with the aim to obtain a definition useful to the confrontation with the prescriptive definition. Following this aim it is important to quote Dahl and Sartori to try to obtain this "condensed" and final empirical definition. Debating with the theorists of élite, Dalh wrote that the contemporary political system is a "Polyarchy"(Dahl 1971), or rather a political system that is characterized by the government of several relatively autonomous élites and by several minority oppositions where 
the government has a continuous capability of answering to the preferences of its citizens, considered politically equal (Sola 2004: 649). This "Polyarchy", with its characteristics, represents once more a type of minimal definition of Democracy that, however, can become a "condensed" definition with the integration of the procedural definition's hub: the mechanism. About the above it is useful to utilize Sartori's descriptive definition that says that Democracy is a mechanism (and here the reference is to Schumpeter's definition, as Sartori wrote the same) that creates an open polyarchy from which a competition comes out of the electoral market that gives people power and, specifically, imposes the "responsiveness" of elected members towards the voters (Sartori 2000: 108). This definition can be accepted as a good descriptive, "condensed" and firm, definition of contemporary Liberal Democracy.

For the prescriptive definition of contemporary Democracy there are many different positions among the experts. Morlino thinks that it can be defined simply as the regime that should create the best institutional opportunity to obtain liberty and equality, the two values he considers essential in contemporary Democracy (Morlino 2003: 27). Bobbio, as Canfora notices, stood between two definitions of Democracy: one is the minimal that is quoted above and the other, that is similar to a prescriptive definition, states that Democracy is that regime that, compared to the values, is inspired by the fundamental principle of formal and also substantial equality of all men (Canfora 2005). Sartori works on the prescriptive definition of vertical Democracy writing that good Democracy should be an elective meritocracy because he thinks that the only equality useful to the whole society is equality according to merit (Sartori 2000: 117). Held proposes an instrumental democratic principal of autonomy, formed by equal rights and equal obligations to determine conditions of the citizens' life, to try to determine a Democratic view to eunomia (Held 1997: 409-458). Zagrebelsky, in his book on democratic pedagogy, writes about a whole of "should be" linked with Democracy as relativism in the relationship with different identities, mistrust towards irreparable decisions, experimental attitude, conscience of majority and minority, altruistic attitude and care to words (Zagrebelsky 2005: 25-43).

Such different thoughts, respecting the approach of political theory, would lead to different and, likely, strongly conflicting theories of Democracy. So a possible answer to the question that springs out spontaneously "Which theory of Democracy?" can now be attempted.

\section{Theory of Democracy, criticisms and proposals}

The analysis performed up to now on contemporary Democracy brings to a number of different standings about the prescriptive definition of Contemporary Democracy that makes the drafting of a meaningful political theory on Democracy very problematic. To try to answer the question that names this paper, it is important to firstly resolve the problem with regards to the prescriptive definition in order to arrive to a complete definition of Democracy. 
When the problem linked to prescriptive definition of contemporary democracy is tackled it is important to stress that this type of Democracy is a LiberalDemocracy, and that it isn't a pure Democracy (like the Classic type described above) and that, at the same time, if the term Democracy linked with the actual political system is to be used, it will include in its meaning an important role of Democracy in the contemporary hendiadys Liberal-Democracy. In fact, "defining Democracy is important because it establishes what we expect from Democracy" (Sartori 2000: 11) and, given that Democracy stays for something, it is fundamental, to obtain a prescriptive definition to understand what the current meaning of the concept is and what the "should be" meaning of it will be; then, this work will go on with the relationship (in prescriptive scope) between contemporary liberalism and contemporary Democracy.

In the Classic Democracy the central values were isegoria and isonomia and civic virtue. In the modern thought of Democratic thinkers (strangely Sartori in his work omits to include in the Democratic thought of nineteenth century some fundamental authors, as in Sartori , 2000: 110) the importance of this values appeared unaltered as in Michelet, Mazzini, Fröbel, Lowett (important for the chartist movement), Lamartine (Fenske 2004: 43-54). The difference lies on the universal significance that this values, united with the motto "equality, liberty and brotherhood", assumed after the French Revolution. The man of nineteenth century, differently of ancient Greeks, wanted to change the world and they were sure to live in revolutionary times that would permit them to modify the past structure. The providential vision of history and the faith in the natural equality of people (that is distant to ancient Greeks' strong use of slavery) created in the Democrats the aspirations towards a new society founded on the equality of the citizen. The contemporary democratic "should be", presents itself as a "idealized" model of the classic Democracy with the deification and the universalisation of the role of the people (when for the people stands for the persons who live in the same political space, and here the difference with classic citizenship is too big) that represents the foundation of sovereignty and the telos of the political activity. The transfigured link with classic democracy values allows to contemporary Democracy to continue to use the term, because a part of the classic prescriptive meaning continues to survive in the new formulation of the idea. Specifically, the part that survives and that is central to continue to use the term is the central role of the values of isegoria and isonomia, whereas the difference between the two lies in the extension of citizenship from the few of ancient Greek citizen to the whole of the people in the contemporary Democracy.

Leaving out the isonomia that is a political premise and result of Democracy, the problem that such ideas meet in the contemporary political systems, characterized by big national states in a contest of indirect rule by the people, is that to give possible isegoria (that is the equal capability of the citizens to take part in public politic) they don't have to realize only the condition for all the citizens to take a part in "active" electorate (that is reachable through political equality) but they also have to realize the condition for all the citizens to take a part in "passive" electorate (that is reachable through social 
equality). For social equality the Democrats don't have the idea of arithmetic equality (for all the same) but they intend, for social equality, that condition asserting that "no citizen can be so rich to be able to buy another and no citizen can be so poor to be bought by others" (Rousseau 1970: 738).

So the prescriptive definitions of contemporary Democracy, that is deducible from the Democratic contemporary thought, is that form of government where there is the complete harmonic and virtuous sovereignty of the people, intended as a whole of equal persons that can equally decide and take a part in politic because their social, legal and political conditions are equal.

Such definition resolves only the first part of the problem. Contemporary democracy is a Liberal-Democracy and so this definition needs to be integrate with prescriptive liberal idea of government, where, going back to Cofrancesco typology, people, that are in legal competition one against the other, that have the best capability to govern lead the political system. The prescriptive definition of contemporary Democracy that tries to express the link between Liberalism and Democracy is Sartori's one, starting from the right observation that contemporary Democracy is a vertical Democracy. From such observation Sartori goes as far as defining prescriptive democracy as elective meritocracy (as written above). He emphasized, the liberal idea that only the best "should govern". On the above Sartori thinks that meritocracy is linked with democratic equality of opportunity, that he considers as the equally open offer to climb the social vertical system according to the selection of the most meritorious. But he doesn't state that a democratic value (independently of the general judgment on meritocracy) but only a liberal value because the merit of meritocracy is given by a objective idea of merit that isn't the democratic idea of merit according to the one the choice on capabilities and merit stays in the will of the people. There is a strong relativistic attitude in the choice of good and wrong in Democracy (Zagrebelsky 2005: 25) where what is important is that all the people have the chance to chose according to their ideas (that is the true democratic equality of opportunity, or the opportunity to all the people to create and built a merit and not to be able to compete by "the merit") and not that all the people have the possibility to go up following a standard merit. Summarizing, there is in Sartori a scientist idea of politics that, even though it may or may not be shareable, is surely Liberal and not Democratic, at least utilizing Cofrancesco's typology.

Such meritocratic definition is anyway useful to take too liberal prescriptive definition of contemporary democracy. Sartori's definition is too Liberal because, as stated above, the values of Democratic thought have to influence in a stronger way than liberal values the prescriptive meaning of the contemporary hendiadys Liberal-democracy does, if it wants to continue to be called only with the term "Democracy", and this doesn't happen with Sartori's definition that proposes a Liberal idea of meritocracy as a prescriptive form of Democracy. 
It is now possible to try to formulate a prescriptive definition of contemporary democracy that, considering liberal presence and its values, gives to democratic values an important role, guaranteeing with this method the link between the term "Democracy" and the historical meaning of the word. Such definition can be so: that political system where all the citizen are put in condition to compete (Liberal insertion) to carry out and create the public "will", within the law (other liberal insertion).

\section{Which theory of Democracy? A possible conclusion}

From this prescriptive definition of contemporary democracy it is possible to try to delineate an answer to the starting question- which theory of Democracy?- through the possible comparison (according to political theory, as described above) between studies and empirical definition on to be of democracy (that are derived from political science, as examined above) and studies on the values of democracy over history (that are derived from the history of political thought, as shown above). Contemporary Democracy, following this approach, is an open vertical polyarchy where all the citizens should have the complete capability to influence (also to think beyond) and take part in the mechanisms and competitions that create the public politics. Such public politics should be, in the limits established by the law, too near to the "will" of the same citizens. It can also be said that modern Democracy has been dealing with changing times and societies during the last thirty years; the post-modern age is a new, tough challenge to modern values that have in some way identified contemporary Democracy. Such challenge, leads to a reconsideration of the original values of ancient Democracy. This process takes place every time there is a clash among values in Western society because, in order to bridge the gap created by the latter, intellectuals elaborate theories and possible meanings of the "origins". Therefore, there is the possibility that post-modern Democracy will be a renewed union between the old and the new, between different but converging heritages of the two patterns of Democracy that have been analysed in this paper. In conclusion, it is possible to claim that in order to find an answer to the word Democracy it is necessary to confront the identity at its origins and the various problems typical of the specific historical context taken into account. During the $20^{\text {th }}$ century this combination of elements was embodied by political methodology of liberal thinkers and the political equality of the "polites". In the future, the old Greek identity of Democracy might rise up to new heights.

\section{References}

Bobbio, N 1986, "Congedo", in Bonanate, L\& Bovero M (eds.), Per una teoria generale della politica. Studi dedicati a Norberto Bobbio, Passigli, Firenze.

Bobbio, N 1987, "La democrazia dei moderni paragonata a quella degli antichi (e a quella dei posteri)", Teoria Politica, vol.III, n. 3, pp. 3-17.

Bobbio, N 1990, "Per una mappa della filosofia politica", in Fiorot, D (ed.), La filosofia politica oggi, Giappichelli, Torino. 
Bobbio, N 1995a, Il futuro della democrazia, Einaudi, Torino.

Bobbio, N 1995b, Stato, governo, società, Einaudi, Torino.

Bobbio, N, Matteucci, N \& Pasquino G 2004, Il dizionario di politica, Utet, Torino.

Bovero, M. (ed.), 1999, Norberto Bobbio. Teoria Generale della Politica, Einaudi, Torino.

Canfora, L 2004, La Democrazia. Storia di un'ideologia, Laterza, Roma.

Canfora, L 2005, "Oscillazioni per un filosofo", in Corriere della sera 6 February, p. 35.

Carnevali, B 2002, "Il Contratto Sociale: genesi di un classico", in Rousseau, J J, Il Contratto sociale, Mondadori, Milano.

Chabod, F 1974, L'idea di Nazione, Laterza, Roma.

Cofrancesco, D 2003, La Democrazia liberale (e le altre), Rubbettino, Soveria Mannelli.

D'Addio, M 1984, Storia delle dottrine politiche, ECIG, Genova.

Dahl, R A 1971, Polyarchy. Participation and opposition, Yale University Press, New Haven.

Dahl, R A 1989, Democracy and Its Critics, Yale University Press, New Haven-London.

Dahl, R A 2002, Sulla democrazia, Laterza, Roma.

Dahl, R A 2003, Quanto è democratica la costituzione americana?, Laterza, Roma.

Erodoto 1990, Le Storie, Libro III, Fondazione Valla, Milano.

Fenske, H 2004, Il pensiero politico contemporaneo, Il Mulino, Bologna.

Finley, M I 1973, La democrazia degli antichi e dei moderni, Laterza, Bari.

Fukuyama, F 1992, The End of History and the Last Man, The Free Press, New York.

Hamilton, A, Jay, J \& Madison, J 1788, The Federalist, MacLean, New York, trans. 1980, Il Mulino, Bologna.

Held, D 1996, Models of democracy, Polity Press, Cambridge, trans. 1997, Modelli di democrazia, Il Mulino, Bologna.

Hobsbawm, E J 1979, Il trionfo della borghesia, Laterza, Roma.

Hobsbawm, E J 2004, Il secolo breve, BUR, Milano.

Kelsen, H 1981, La democrazia, Il Mulino, Bologna.

Lijphard, A 200, Le democrazie contemporanee, Il Mulino, Bologna. 
Marradi, A 1984, "Teoria: una tipologia dei significati", Sociologia e ricerca sociale, vol. V, n.13, pp. 157-81.

Marx, K 1948, "La guerra civile in Francia", in Il partito e l'internazionale, Rinascita, Roma.

Marx, K \& Engels, F 1972, La sacra famiglia, Editori Riuniti, Roma.

Marx, K \& Engels, F 1999, Manifesto del partito comunista, Laterza, Roma.

Mattew, H C 2002, “L'età liberale” in O' Morgan, K, Storia dell'Inghilterra, Bompiani, Milano.

Montesquieu 2005, Lo spirito delle leggi, Utet, Torino.

Morlino, L 2003, Democrazie e democratizzazioni, II Mulino, Bologna.

Musti, D 1997, Demokratía, Laterza, Roma.

Musti, D 2003, Introduzione alla storia greca, Laterza, Roma.

Paine, T 1995, Rights of Man, Common Sense, and Other Political Writings, Oxford University Press, Oxford.

Rousseau 1970, Scritti politici, Einaudi, Torino.

Sartori, G 1995, Elementi di teoria politica, Il Mulino, Bologna.

Sartori, G 2000, Democrazia: Cos'è, BUR, Milano.

Sartori, G 1979, La politica. Logica e metodo in scienze sociali, Sugar and co., Milano.

Sartori, G 2006, Democrazia. Ha un futuro?, in AA.VV., Lezioni Bobbio, Einaudi, Torino.

Sen, A 2004, La democrazia degli altri: perchè la libertà non è un' invenzione dell'occidente, Mondadori, Milano.

Schumpeter, J A 1942, Capitalism, Socialism and Democracy, Harper, New York.

Soboul, A 1997, Storia della Rivoluzione Francese, Bur, Milano.

Sola, G 2004, Storia della scienza politica, Carocci, Roma.

Testi, A 2003, La formazione degli Stati Uniti, Il Mulino, Bologna.

Tocqueville, A 1835-1840, La Démocratie in Amérique, Paris ; trans. 1968, La Democrazia in America in Scritti Politici, Utet, Torino.

Urbinati, N 1997, L'individualismo democratico, Donzelli, Roma.

Zagrebelsky, G 2005, Imparare la Democrazia, Gruppo editoriale l'Espresso, Roma. 
Zolo, D 1985, “I possibili rapporti tra filosofia politica e scienza politica”, Teoria Politica, vol. I, n. 3, pp. 91-109. 